\title{
LAMINATED WOOD AND MULTIMATERIAL WOOD - ADHESIVE MESHAS REPLACEMENTS OF SOLID WOOD IN RESTORATION OF HISTORICAL BUILDINGS
}

\author{
I. Macedo Alquicira ${ }^{1 *}$, J. R. Sotomayor Castellanos ${ }^{2}$, F. J. Castro Sánchez ${ }^{3}$ \\ ${ }^{1}$ Universidad Michoacana de San Nicolás de Hidalgo, Morelia, México - macedoisarael@gmail.com \\ ${ }^{2}$ Universidad Michoacana de San Nicolás de Hidalgo, Morelia, México - madera999@yahoo.com \\ ${ }^{3}$ Universidad Michoacana de San Nicolás de Hidalgo, Morelia, México - maderadesarrollo2764@ gmail.com
}

KEY WORDS: humidity contents, density, ultrasound, dynamic module, quality factor, $P$. pseudostrobus

\begin{abstract}
:
Wooden structure restorationwork in historical buildings requires substitution and/or reparation of structural elements. The aim of this investigation is to compare the density, wave velocity, dynamic module, and quality factor intest pieces of solid wood, laminated wood and a multimaterial of $P$. pseudostrobus. The work hypothesis proposes that dynamic modules of laminated wood and multimaterial laminated wood reinforced with stainless steel mesh are, at least, equal to solid wood. Small dimension test pieces made of solid wood, laminated wood, and multimaterial wood elaborated with the species $P$. pseudostrobus were prepared. Humidity content and apparent density of wood were determined. Ultrasound tests in radial, tangential, and longitudinal direction were doneand wave velocity, dynamic module, and quality factor were determined. Empiric evidence indicates that wave velocity, dynamic module, and quality factors are different with the three kinds of test pieces. Laminated wood and multimaterial wood characteristics are similar to $P$. pseudostrobus solid wood; so that the two compound material have good expectations to substitute some pieces that work as resistance elements in wooden structures.
\end{abstract}

\section{INTRODUCTION}

\subsection{Problem}

Wooden structure restoration work in buildings with historical and cultural value requires the reparation and/or, eventually, the substitution of structural elements such as beams, columns,girdersand the components of roof truss, walls, floors and stairways. (Van Roy et al., 2018) In order to respect the wooden historical structures preservation principles of the International Council on Monuments and Sites (ICOMOS, 1999), it is necessary to substitute some pieces of wood which are deteriorated by new elements of the same species and with technological quality equivalent to the wood in service (Cruz et al., 2015).

The person in charge of the restoration faces the problem of scarcity of wood pieces comparable in dimensions and similar to the structural elements in service. A practical solution to this problem is to elaborate reinforced and/or reconstructed laminated wood piecesthat satisfy the mechanical resistance criteria, in such a way that reliable structural criteria and the renovated structural service can be assured (Croatto y Turrini, 2014; Larsen y Marstein, 2016).

\subsection{Reinforced Wood}

Some elements made of wood, such as recycled beams used to support flexion charges, have been submitted for replacement or reinforcement with classical techniques which involve the use of common construction materialsuch as concrete or steel (Borriet al, 2005). However, literature reports new approaches and new technology in order to repair, restore and reinforce some pieces of wood present in buildings where wood plays an important role.

Recent research about the topic, reinforcement and reparation of structural wood elements, preferably studies beams of solid and laminated wood, that potentially or in-service structures exist for future edifications. For example, Jasiénko y Nowak (2014) reinforced beams with new and old wood with the purpose of evaluating different configurations of epoxy adhesive and flexion tested steel plaques; likewise, Frankeet al. (2015) reported different reinforcement techniques for beams depending on the kind or origin of the failure.

A favored strategy to reinforce pieces of wood is the use of carbon fiber reinforced polymer (CFRP). Schober et al (2015) recommend CFRP to repair and reinforce wood structures. In order to improve mechanical resistance in pieces of wood, Corradi et al (2015) add CFRP to pieces of solid wood of Castañee Sativa, while Nadir et al. (2016) did it with laminated wood of Hevea Brasiliensis. Reis et al (2018) recommend CFRP soaked bars to reinforce wood beams.

Particularly, working in historical buildings, Nowak et al (2013) added CFRP to reinforce Pinus Sylvestris beams in order to restore charge capacity in wooden beams. Chang (2015) reviews different techniques to reinforce and to repair wooden columns and walls, while Gubana (2015) did the same on wooden floors. Rescalvo et al (2017) and Rescalvo et al (2018) use different configurations of CFRP to reinforce Pinus Sylvestris old wood, and to analyze the increment in mechanical resistance.

\footnotetext{
* I. Macedo Alquicira
} 
From another point of view, Zhou et al. (2011) report some results about the incorporation of galvanized steel mesh to reinforce wood. Marzi (2015) reviews the prospective of Nanostructured materials to protect and reinforce wooden structures. Byeon et al (2016) do some research on hybrid structural elements made of wood and other materials. Togay et al (2017) propose to reinforcestructural elements with aluminum mesh. Rangavar (2017) reports physical and mechanical properties found in cement-wood panels reinforced with steel mesh, while Kohl et al (2017) characterizemultimaterial based on wood dynamic conditionsand they suggest them as substitution to solid wood.

Synthetizing, the already mentioned authors' conclusions, contemporary tendency is to reinforce pieces of wood by incorporating synthetic and metallic material components in order to improve its technological properties. This way, substituting structural elements in restoration works in historical or damaged buildings would be done only because of exceptional events such as fire or earthquakes.

\subsection{Ultrasound Characterization}

Ultrasound technology applies in engineering analysis of historical wooden structures to measure the wave velocity (Íñiguez- González et al. 2015, Kloibe ret al. 2016, Branco et al. 2017, Riggio et al. 2018). Likewise, ultrasound is used in solid wood mechanical (Tipper et al.2016) and laminated (Sanabria $e t$ al 2011) characterization.

The necessary parameters to characterize dynamically the test pieces with different compounds of wood are the apparent density (Niklas and Spatz, 2010) and the wave velocity in three directions of anisotropy of wood (Dackermann et al, 2016).By combining wave density and velocity the dynamic module is determined (Gonçalves et al, 2014). Another parameter in the mechanical design is the quality factor, which is similarly usedto classify and to compare the quality of wood (Spycher et al 2008). A significant factor of quality suggests better resistance in relation with its density and good appreciation of wood as engineering material. (Ashby, 2011).

These characteristic have been reported for solid and laminated Pinus pseudostrobus Lindl wood done in the Laboratory of Wood Mechanics in the School of Wood Technology of the Universidad Michoacana de San Nicolas de Hidalgo, in Morelia, Mexico (Sotomayor et al, 2010, Sotomayor et al, 2015). However, information about multimaterial wood-adhesive-mesh characterized by ultrasound characterization was not found.

\subsection{Hypothesis}

Work hypothesis proposes that dynamic modules of laminated wood and multimaterial are, at least, equal to solid wood of Pinus pseudostrobus. This hypothesis can be verified if density and wave velocity are determined and dynamic modules are calculated.

\subsection{Objective}

The objective of this research is to compare the density, wave velocity, dynamic module and quality factor on three samples of test pieces of solid wood, laminated wood and multimaterial, all of which were taken from the specie Pinus pseudostrobus. As a corollary, laminated wood and multimaterial have been proposed as a substitute of solid material of pieces of wood in the restoration of historical buildings.

\section{METHODOLOGY}

\subsection{Material}

The experimental material consisted on three groups of 32 test pieces of sawed wood from P. pseudostrobus (Sáenz et al.2011) collected in the State of Michoacán, Mexico. The first group consisted of test pieces made of solid wood labeled as solid wood (Figure 1). The second group was formed by two sheets of wood joined together by an adhesive made of two components of polyurethane (50\%-50\%) labeled as laminated wood (Figure 2).

The third group, named multimaterial (figure 3) was made of two sheets of solid wood and between them a mesh of galvanized steel. (AISI 304 Stainless Steel Mesh). Wood pieces and the mesh were joined together with an adhesive made of two components of polyurethane. Both the laminated and the multimaterial test pieces were made-up under a pressure of $200 \mathrm{~kg} \mathrm{~cm}^{2}$ and a temperature of $80^{\circ} \mathrm{C}$ during 30 minutes. The dimensions of the test pieces were $0,4 \mathrm{~m} \mathrm{x} 0.05 \mathrm{~m} \times 0,1 \mathrm{~m}$ in radial (R), tangential (T) and longitudinal (L) direction.
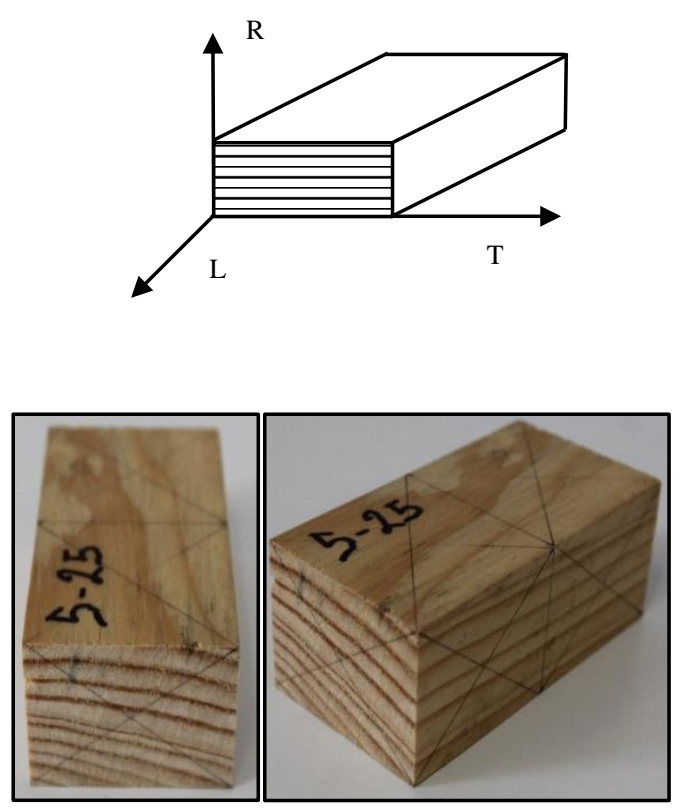

Figura 1. Solid Wood. 

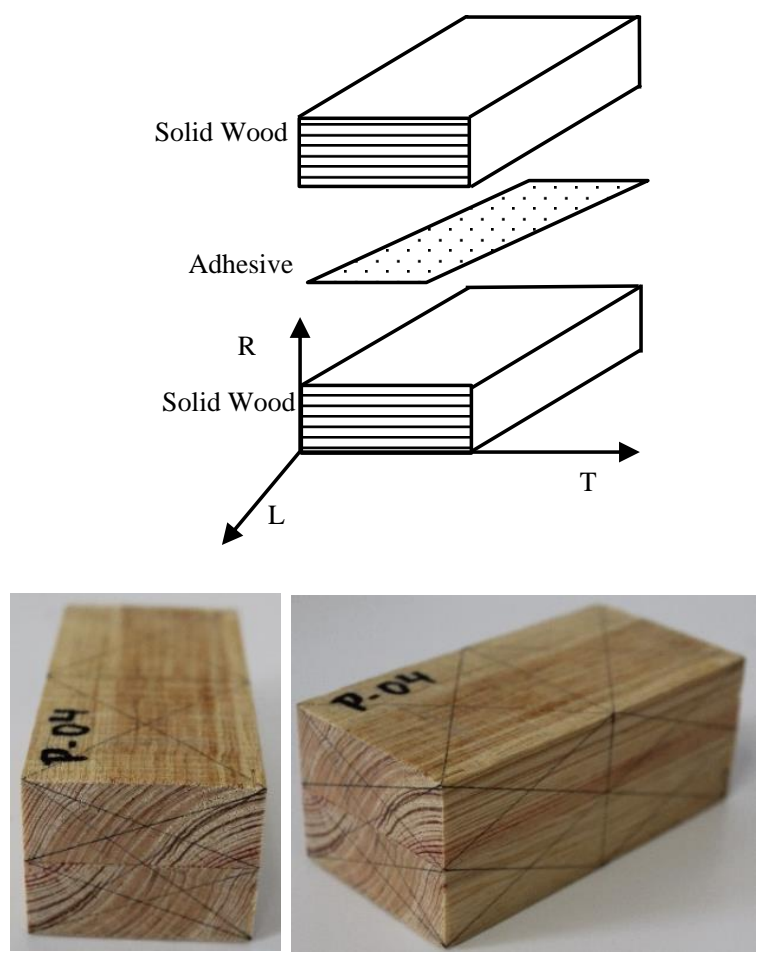

Figura 2. Laminated Wood.
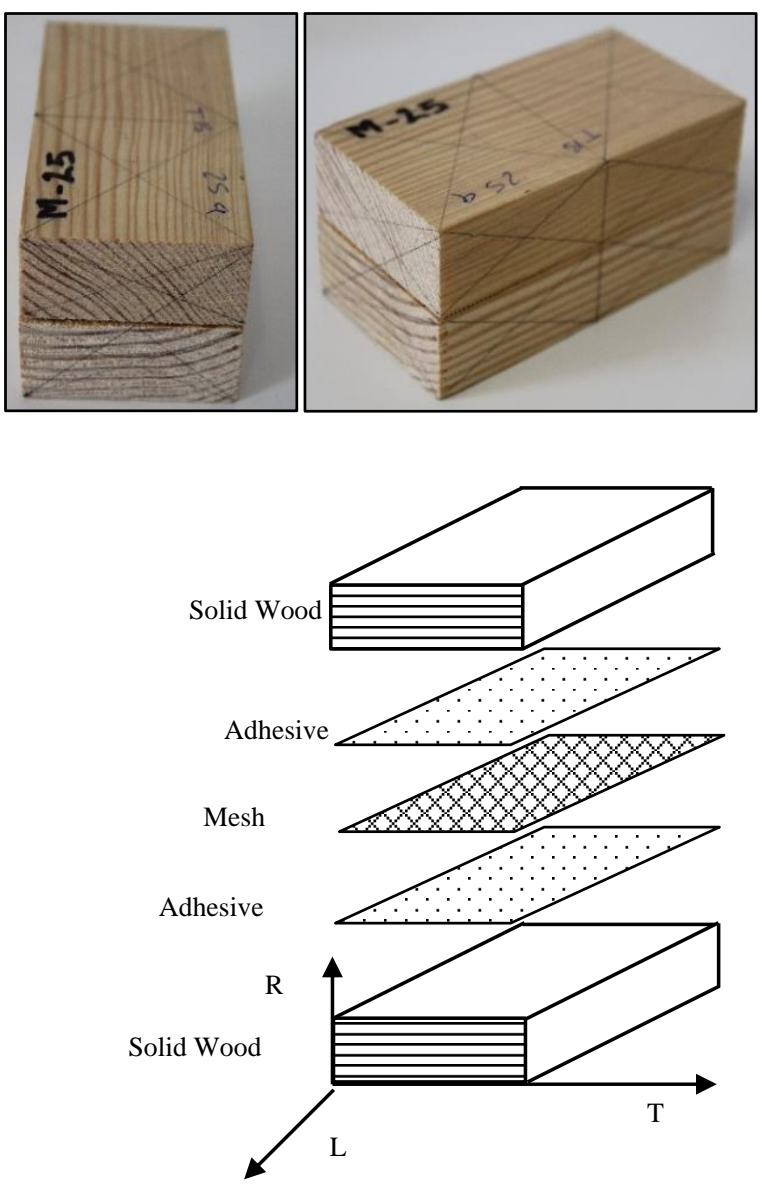

\subsection{Test Program}

Both the wood and the test pieces were stabilized before and after fabrication during 3 months in a conditioning chamber with a temperature of $20^{\circ} \mathrm{C}\left( \pm 1^{\circ} \mathrm{C}\right)$ and an air relative humidity of $65 \%$ $( \pm 2 \%)$, until they reached a constant weight. The apparent density of the test piece (ph) was determined taking into consideration the relation between weight and volume at the moment of the test, corresponding to the content of humidity in equilibrium (International Organization for Standardization ISO 13061-1:2014). With the objective of simplifying the text, from here on the term 'apparent density' will be named 'density'. The content of humidity $(\mathrm{H})$ of the wood was determined with the relation between the weight at the moment of the tests and the weight in an anhydrous state (International Organization for Standardization ISO 13061-1:2014).

The ultrasound tests consisted on measuring the wave transmission time with the apparatus Sylva test $\odot$ (frequency 22 $\mathrm{kHz}$ ) and dividing it by the distance between the ultrasound signal of emission and reception, located on the radial (R), tangential (T), and longitudinal (L) direction, normal to the corresponding contacting surfaces (RT, RL, and TL). Ultrasound velocity (Vus) was calculated in relation to transmission time/route distance. Three measures were done in each plane in positions 1, 2, 3 as indicated in Figures 4 and 5, so that the test pieces rotated $90^{\circ}$ in order to get normal direction to the contact planes.
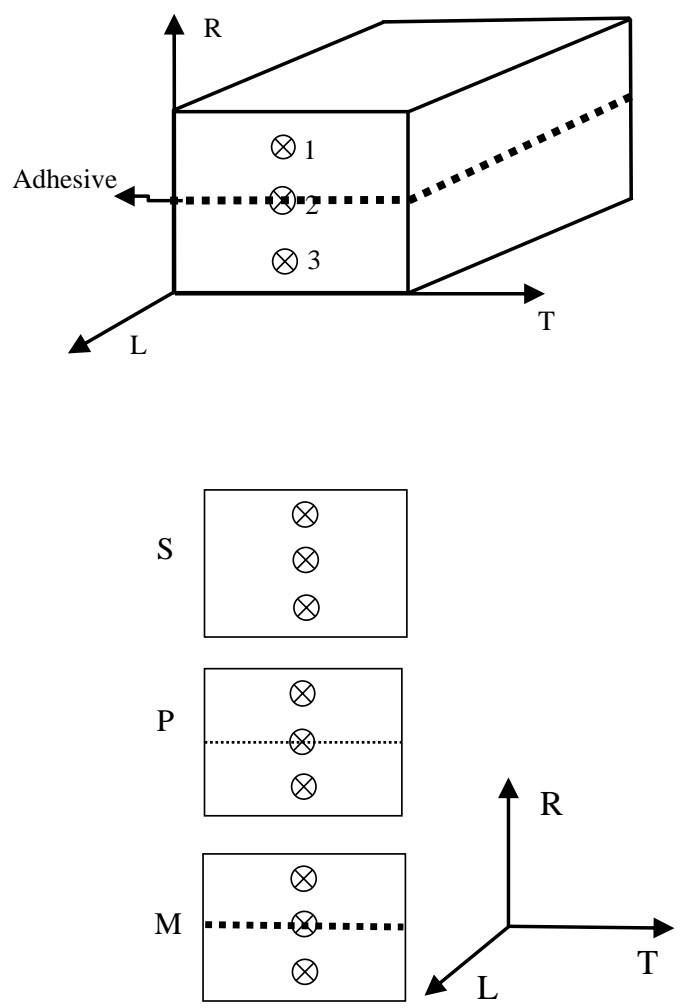

Figura 3. Multimaterial. 


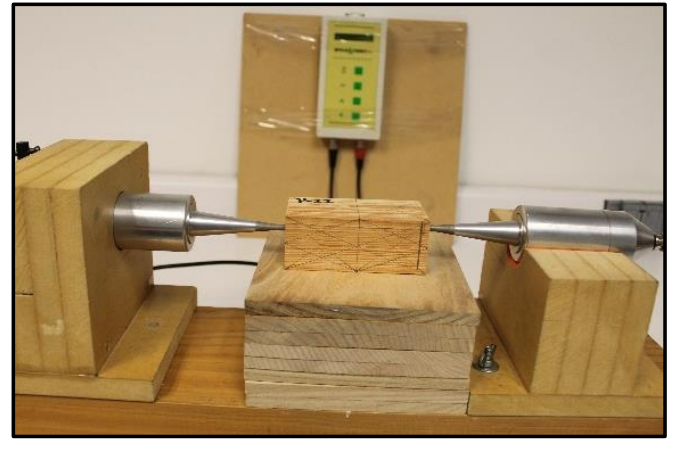

Figure 4. Ultrasound tests in the longitudinal direction.
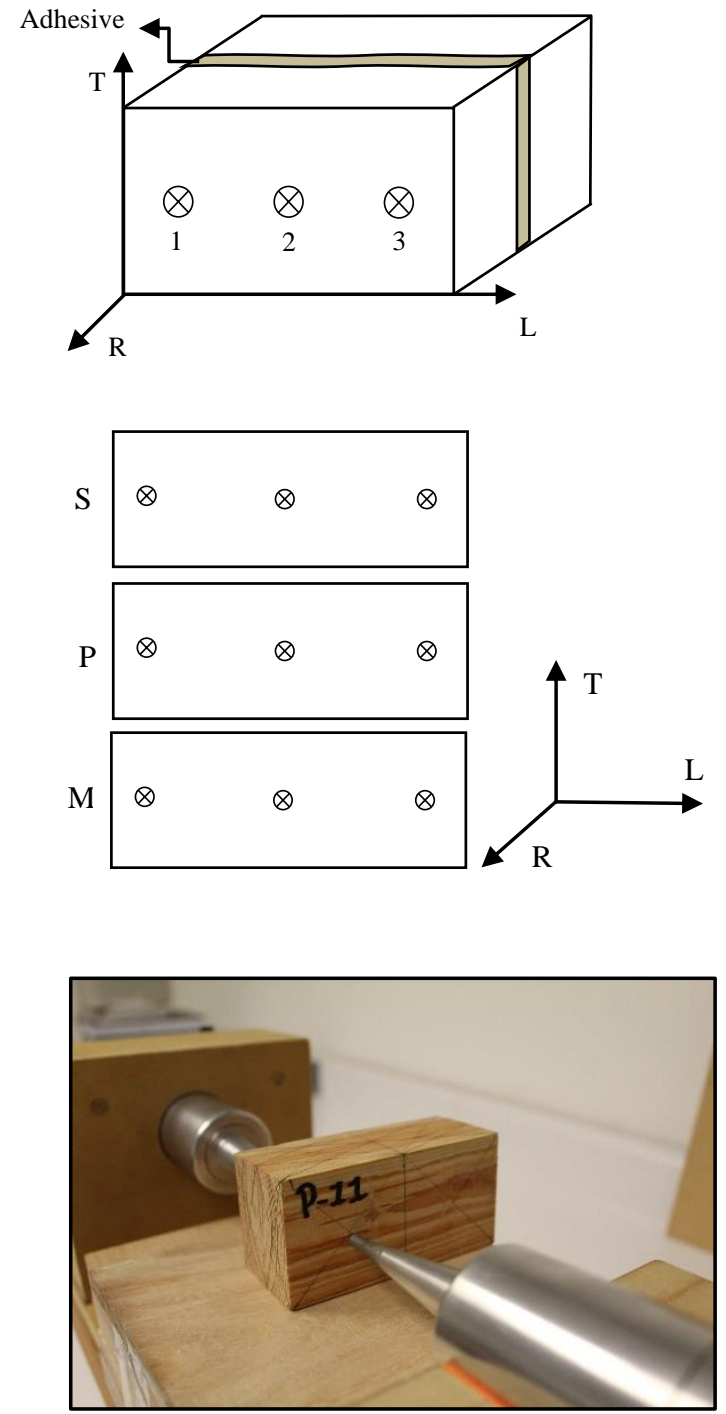

Figure 5. Ultrasound tests in the tangential direction

The dynamic module was calculated with the equation (1) (Dackermann et al. 2016):

$\begin{array}{ll} & \mathrm{E}_{\mathrm{us}}=\rho_{\mathrm{H}} \times \mathrm{v}_{\mathrm{us}}^{2} \\ \text { Where: } & \text { Eus }=\text { Dynamic module }\left(\mathrm{N} \mathrm{m}^{-2}\right)\end{array}$
$\rho_{\mathrm{H}}=$ Density $\left(\mathrm{kg} \mathrm{m}^{-3}\right)$

Vus $=$ Wave velocity $\left(\mathrm{m} \mathrm{s}^{-1}\right)$

Quality factor was calculated with the equation (2) (Spycheret al. 2008):

Where:

$$
\mathrm{F}_{\mathrm{us}}=\mathrm{v}_{\mathrm{us}} / \rho_{\mathrm{H}}
$$

$$
\text { Fus }=\text { Quality }\left(\mathrm{N} \mathrm{m}^{-2}\right)
$$$$
\rho_{\mathrm{H}}=\text { Density }\left(\mathrm{kg} \mathrm{m}^{-3}\right)
$$

Vus= Wave velocity $\left(\mathrm{m} \mathrm{s}^{-1}\right)$.

\subsection{Research Strategy}

Experimental strategy consisted on determining medium values $(\ddot{X})$, standard deviation $(\sigma)$ and variation coefficient $((\mathrm{CV}=\sigma /$ $\ddot{X})$ of the three samples of test pieces: solid wood, laminated wood, and multimaterial.

In order to analyze the results two physical parameters were specified: humidity content $(\mathrm{H})$ and density $\left(\rho_{\mathrm{H}}\right)$; and also three mechanical parameters: wave velocity $\left(\mathrm{V}_{\mathrm{us}}\right)$, dynamic module ( $\left.E_{u s}\right)$ and quality factor (Fus). The sub index $\mathrm{H}$ means that density corresponds to the content of humidity of the specimen. The sub index (us) indicates that the parameters are derived from ultrasound tests. In the same context, three samples are defined: solid wood, laminated wood and multimaterial; three contact planes: TL, RL, and RT; and three directions of wave velocity: $\mathrm{R}, \mathrm{T}$, and $\mathrm{L}$.

\section{RESULTS AND ANALYSIS}

Table 1 represents density $\left(\rho_{H}\right)$, content of humidity $(H)$, wave velocity $\left(\mathrm{V}_{\mathrm{us}}\right)$, dynamic module $\left(\mathrm{E}_{\mathrm{us}}\right)$, and quality factor $\left(\mathrm{F}_{\mathrm{US}}\right)$ for solid wood, laminated wood and multimaterial.

\begin{tabular}{lccc}
\hline \multicolumn{1}{c}{ Plane-Direction } & TL-R & RL-T & RT-L \\
\hline \multirow{2}{*}{$\rho_{\mathrm{H}}\left(\mathrm{kg} \mathrm{m}^{-3}\right)$} & 589 & 589 & 589 \\
$\mathrm{H}(\%)$ & 11.6 & 11.6 & 11.6 \\
$\mathrm{~V}_{\text {us }}\left(\mathrm{m} \mathrm{s}^{-1}\right)$ & 765 & 685 & 5040 \\
$\mathrm{E}_{\text {us }}\left(\mathrm{MN} \mathrm{m}^{-2}\right)$ & 346 & 291 & 15062 \\
$\mathrm{~F}_{\text {us }}\left(\mathrm{m}^{4} \mathrm{~kg}^{-1} \mathrm{~s}^{-1}\right)$ & 1.30 & 1.16 & 8.55 \\
& & Laminated wood \\
$\rho_{\mathrm{H}}\left(\mathrm{kg} \mathrm{m}^{-3}\right)$ & 583 & 583 & 583 \\
$\mathrm{H}(\%)$ & 10.7 & 10.7 & 10.7 \\
$\mathrm{~V}_{\text {us }}\left(\mathrm{m} \mathrm{s}^{-1}\right)$ & 688 & 692 & 4110 \\
$\mathrm{E}_{\text {us }}\left(\mathrm{MN} \mathrm{m}^{-2}\right)$ & 277 & 366 & 9873 \\
$\mathrm{~F}_{\text {us }}\left(\mathrm{m}^{4} \mathrm{~kg}^{-1} \mathrm{~s}^{-1}\right)$ & 1.18 & 1.19 & 7.05 \\
& & Multimaterial \\
$\rho$ H $\left(\mathrm{kg} \mathrm{m}^{-3}\right)$ & 586 & 586 & 586 \\
$\mathrm{H}(\%)$ & 10.4 & 10.4 & 10.4 \\
$\mathrm{~V}_{\text {us }}\left(\mathrm{m} \mathrm{s}^{-1}\right)$ & 1291 & 493 & 4136
\end{tabular}




$\begin{array}{lccc}\mathrm{E}_{\text {us }}\left(\mathrm{MN} \mathrm{m}^{-2}\right) & 976 & 143 & 10098 \\ \mathrm{~F}_{\text {us }}\left(\mathrm{m}^{4} \mathrm{~kg}^{-1} \mathrm{~s}^{-1}\right) & 2.20 & 0.84 & 7.06\end{array}$

$\rho_{\mathrm{H}}=$ Density; $\mathrm{H}=$ Moisture content; $\mathrm{v}_{\mathrm{us}}=$ Wave speed; $\mathrm{E}_{\mathrm{us}}=$ Dynamic modulus; $F_{u s}=$ Quality factor.

Table 1 Density, humidity content, wave velocity, dynamic module, and quality factor.

\subsection{Moisture Content}

Humidity content of the three samples varies from the interval 10.4 to 11.6 (Table 1). The coefficient variation of humidity content in each sample interior varies from 5.1 to $9.8 \%$. Consequently, $P$. pseudotrobus wood is considered stabilized in dry state and it is proposed that the variation of the humidity content of the sample pieces does not intervene in a significant way in the results.

\subsection{Density}

Density magnitude for solid wood and laminated wood is similar to the ones reported by Sotomayor et al. (2010) for $P$. pseudotrobuswood and for laminated wood of $P$. pseudotrobus, Sotomayor et al (2015). However, no information to compare multimaterial densitycould be found. Laminated wood density decreases $1 \%$ and multimaterial density decreases $0.5 \%$ comparing both with solid wood density. (Table 1). These results suggest that laminated treatment and multimaterial fabrication do not modify in a significant way the density of specimens made only with solid wood.

One of the criteria to substitute a piece of wood while restoring historical buildings is to use the same species, the same density and the same mechanical resistance (Cruz et al 2015) of $P$. pseudotrobussolid wood. It is wise to specifically study the variation in density when reconstituted wood is being fabricated using different species from the one studied in this research, in order for this proposal to be extended to other species.

\subsection{Wave Speed and Dynamic Modulus}

Figures 6, 7, and 8 detail the three dynamic modules (E1, E2, and E3) locally determined in the three positions of the specimens of the three samples according to the sampling strategy detailed in Figures 1 to 5 .

The magnitudes of wave speed and dynamic module in $P$. pseudotrobus solid wood are similar to the ones reported by Sotomayor et al (2010) and Sotomayor et al (2015). However, the average values of $\mathrm{Vu}$ and Eusfor radial and tangential directions in this research (2019) are lower than the ones in the bibliography. This result is consistent with the later analysis of local measurements.

The three dynamic modules determined in radial direction in one specimen are similar among them (Figure 6). Nevertheless, there are variations among the three samples. The average dynamic modules of multimaterial $\left(976 \mathrm{MN} \mathrm{m}^{2}\right)$ are as far as 2.8 times larger than the ones of solid wood $\left(346 \mathrm{MN} \mathrm{m}^{-2}\right)$ and even more, 3.5 times larger than the ones of laminated wood $\left(277 \mathrm{MN} \mathrm{m}^{2}\right)$. This result indicates that in relation to solid wood and laminated wood of $P$. pseudotrobus, multimaterial increases the dynamic module in radial direction.

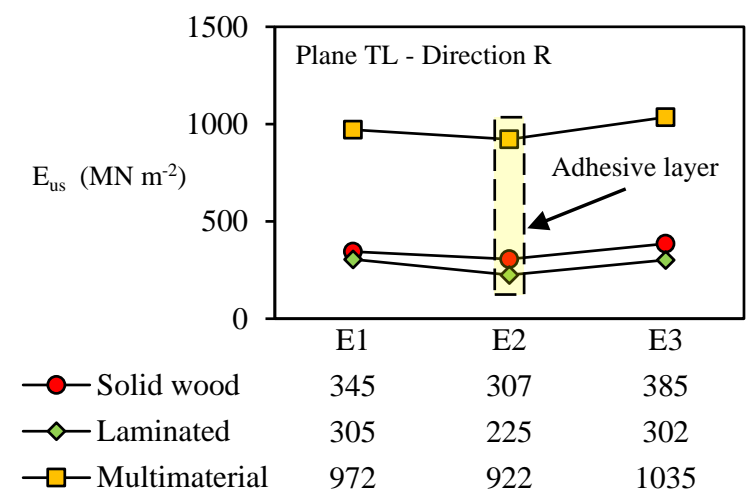

Figure 6 Dynamic Modules in Radial Direction.

The three dynamic modules measured in tangential direction of the specimens for solid wood and multimaterial are similar (Figure 7). However, module E2 for laminated wood, corresponding to the layer where the adhesive is (plane RT parallel to the tangential direction) is larger 7.5 times in relation to solid wood, and 5.6 times larger in relation to laminated wood.

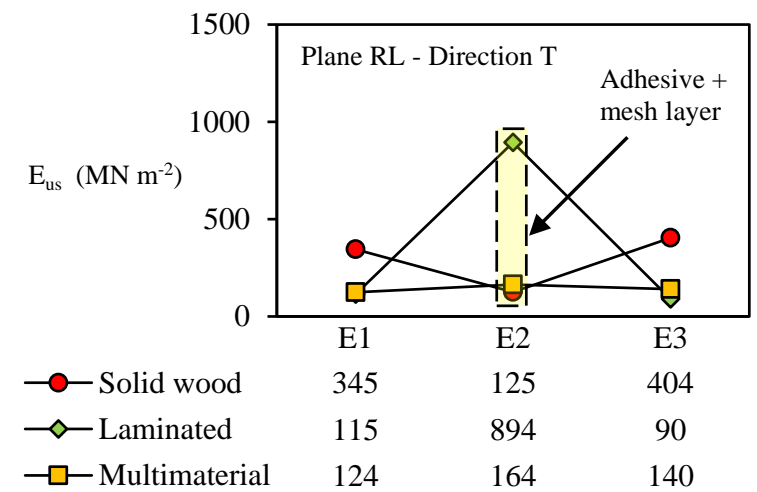

Figure 7 Dynamic Modules in Tangential Direction.

This way, specimens of laminated wood increase their dynamic module at local level because of the presence of adhesive. This phenomenon reflects the increment of the average dynamic module in the specimens of laminated wood in $20.5 \%$ with respect to solid wood and $60.1 \%$ with regard to multimaterial. In the same context, a significant effect of the adhesive mesh plane has not been identified when measuring E1, E2, and E3 of the specimens of multimaterial.

As for the longitudinal direction, normal to the radial-tangential plane, dynamic modules of the specimen of laminated wood, combine withdynamic modules of the specimen of multimaterial (Figure 8). However, the dynamic modules of specimen of solid wood are larger in relation to laminated wood and multimaterial. 


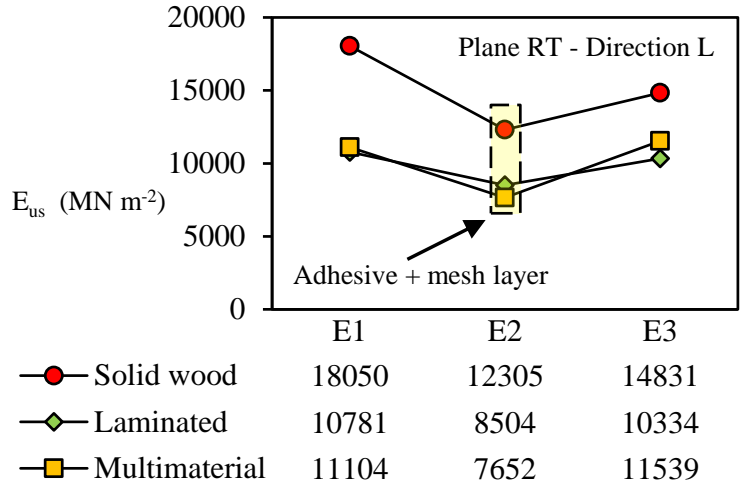

Figure 8 Dynamic Modules in Longitudinal Direction

Dynamic modules of solid wood are,as an average, $35.4 \%$ larger than laminated wood and 33\% largerthan multimaterial. With regard to E2 values corresponding to measures through planes RT of adhesive in specimens of laminated wood and multimaterial aresmallercomparing them with dynamic modules of specimens of solid wood.

Dynamic module is calculated from density and wave velocity with equation (1). This way, when density increases, a lineal increment of the dynamic module is produced. On the other hand, when wave speed increases a second order intensification is provoked in the dynamic module.

\subsection{Quality Factor}

Taking into consideration the three samples studied, the average quality factor, which was calculated with average values of wave velocity and density, they are larger for longitudinal direction comparing it with quality factor corresponding to radial and tangential direction (Figure 9).

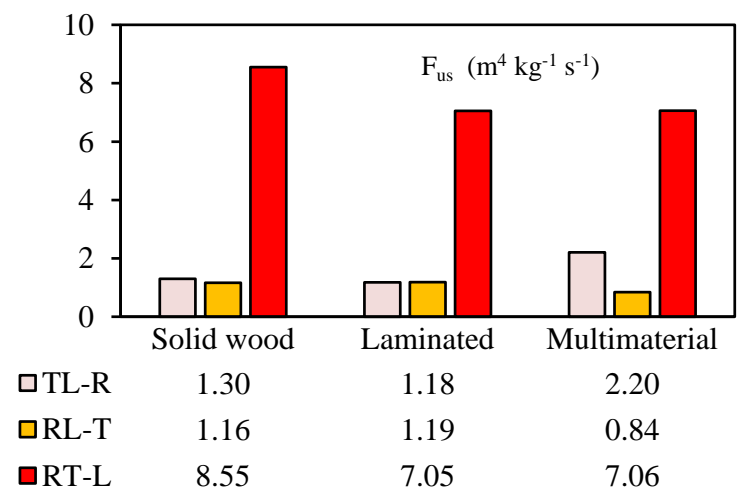

Figure 9 Quality Factor.

These magnitudes represent wave velocity measured in the three directions, radial (R), tangential (T) and longitudinal (L), corresponding to planes TL, RL, and RT, divided by average density of the 32 specimens of the three sample studied.

Particularly, the measurements of the corresponding points of velocity coincident to the adhesive planes (planes TL and RT of laminated wood) and the ones with adhesive and mesh (planes TL and RT of multimaterial) vary comparatively. However, to the purpose of the characterization, these data areintegrated in the values of quality factors.

The magnitudes of quality factor determined in this research (2019) were smaller than the ones reported by Sotomayor et al (2010) for solid wood of P. pseudostrobus

FUSR $=6.97$, FUST $=1.96$, and FUSL $=13.35$, with $\rho \mathrm{H}=436$ $\mathrm{kg} \mathrm{m}^{-3}$ y $\mathrm{H}=10.63 \%$.

\section{CONCLUSIONS}

Density variation among the three samples did not vary significantly. This way it is possible to infer that anisotropy of wave velocity in wood is the parameter that characterizes the magnitude of the dynamic module in each one of the directions of the specimens. However, it is necessary to consider the effect at local level of the adhesive and the mesh that are the components of laminated wood and multimaterial.

Wave velocity, dynamic module and quality factor are different for the pieces of solid wood, laminated wood and multimaterial, which were fabricated with the species $P$. pseudostrobus. This conclusion is valid comparing different groupsof the studied specimens, but among the same directions of anisotropy observed.

Quality factor of laminated wood is similar to solid wood. This way, this compound may substitute solid wood in wooden structures. In the same context, the quality factorcorresponding to radial direction suggests that, in that direction, rigidity of multimaterial is larger than the ones in solid wood and laminated wood, comparatively.

Laminated wood and multimaterial characteristics are similar to the ones in solid wood of $P$. pseudostrobus. This way, the two compound materials have good prospects to substitute structural elements which work as resistance elements in wooden structures.

It is recommended to do intensive research with different species and configurations of test pieces as well as to use other kinds of non-intrusive and destructive tests in order to improve the characterization of laminated wood and multimaterial.

\section{ACKNOWLEDGMENTS}

This research was sponsored by Consejo Nacional de Ciencia y Tecnología de México and bythe Programa de Doctorado en Ciencias y Tecnología de la Madera de la Facultad de Ingeniería en Tecnología de la Madera, de la Universidad Michoacana de San Nicolás de Hidalgo, en Morelia, Michoacán, México. 


\section{REFERENCES}

Ashby, M. F. 2011. Materials selection in mechanical design. London, Butterworth-Heinemann. 640 pp.

Borri, A., Corradi, M., and Grazini, A. 2005. A method for flexural reinforcement of old wood beams with CFRP material. Composites: Part B, 36, pp. 143-153.

Branco, J. M., Sousa, H. S., and Tsakanika, E. 2017. Nondestructive assessment, full-scale load-carrying tests and local interventions on two historic timber collar roof trusses. Engineering Structures, 140, pp. 209-224.

Byeon, J. W., Cho, Y. J., Lee, J. R., and Park, H. M. 2016. Static Bending Strength Performance of Domestic Wood-Concrete Hybrid Laminated Materials. Journal of the Korean Wood Science and Technology, 44(1), pp. 48-56.

Chang, W. S. 2015. Repair and reinforcement of timber columns and shear walls. A review. Construction and Building Materials, 97, pp. 14-24.

Corradi, M., Righetti, L., and Borri, A. 2015. Bond strength of composite CFRP reinforcing bars in timber. Materials, 8(7), pp. 4034-4049.

Cruz, H., Yeomans, D., Tsakanika, E., Macchioni, N., Jorissen, A., Touza, M., Mannucci, and M., Lourenço, P. B. 2015. Guidelines for On-Site Assessment of Historic Timber Structures. International Journal of Architectural Heritage, 9(3), pp. 277-289.

Dackermann, U., Elsener, R., Li, J., and Crews, K. 2016. A comparative study of using static and ultrasonic material testing methods to determine the anisotropic material properties of wood. Construction and Building Materials, 102, pp. 963-976.

Franke, B., Franke, S., and Harte, A. M. 2015. Failure modes and reinforcement techniques for timber beams. State of the art. Construction and Building Materials, 97, pp. 2-13.

Gonçalves, R. A., Trinca, J., and Pellis, B. P. 2014. Elastic constants of wood determined by ultrasound using three geometries of specimens. Wood Science and Technology, 48(2), pp. 269-287.

Croatto, G., and Turrini, U. 2014. Restoration of historical timber structures. Criteria, innovative solutions and case studies. In: Restoration of historical timber structures. Lourenço, P. B., Branco, J. M., and Sousa, H. S. (eds.). pp. 119-136.

Gubana, A. 2015. State-of-the-Art Report on high reversible timber to timber strengthening interventions on wooden floors. Construction and Building Materials, 97, pp. 25-33.

Íñiguez-González, G., Arriaga, F., Esteban, M., and Llana, D. F. 2015. Reference conditions and modification factors for the standardization of nondestructive variables used in the evaluation of existing timber structures. Construction and Building Materials, 101, pp. 1166-1171.

International Council on Monuments and Sites (ICOMOS). 1999. Principles for the Preservation of Historic Timber Structures. México, ICOMOS. 3 pp.
International Organization for Standardization. 2014. ISO 13061-1:2014. Physical and mechanical properties of wood. Test methods for small clear wood specimens. Part 1: Determination of moisture content for physical and mechanical tests. International Organization for Standardization. Brussels, Belgium. 4 p.

International organization for standardization. 2014. ISO 130612:2014. Physical and mechanical properties of wood. Test methods for small clear wood specimens. Part 2: Determination of density for physical and mechanical tests. International Organization for Standardization. Brussels, Belgium. 5 p.

Jasieńko, J., and Nowak, T. P. 2014. Solid timber beams strengthened with steel plates. Experimental studies. Construction and Building Materials, 63, pp. 81-88.

Kloiber, M., Reinprecht, L., Hrivnák, J., and Tippner, J. 2016. Comparative evaluation of acoustic techniques for detection of damages in historical wood. Journal of Cultural Heritage, 20, pp. 622-631.

Kohl, D., Long, T. H. N., and Böhm, S. 2017. Wood-Based Multi-Material Systems for Technical Applications. Compatibility of Wood from Emerging and Developing Countries. Procedia Manufacturing, 8, pp. 611-618.

Larsen, K. E., and Marstein, N. 2016. Conservation of Historic Timber Structures. An ecological approach. Oxford, United Kingdom, Butterworth-Heinemann. 129 pp.

Marzi, T. 2015. Nanostructured materials for protection and reinforcement of timber structures: A review and future challenges. Construction and Building Materials, 97, pp. 119130

Nadir, Y., Nagarajan, P., Ameen, M., and Muhammed, A. M. 2016. Flexural stiffness and strength enhancement of horizontally glued laminated wood beams with GFRP and CFRP composite sheets. Construction and Building Materials, 112, pp. 547-555.

Niklas, K. J., and Spatz, H. C. 2010. Worldwide correlations of mechanical properties and green wood density. American Journal of Botany, 97(10), pp. 1587-1594.

Nowak, T. P., Jasieńko, J., and Czepiżak, D. 2013. Experimental tests and numerical analysis of historic bent timber elements reinforced with CFRP strips. Construction and Building Materials, 40, pp. 197-206.

Tippner, J., Hrivnák, J., and Kloiber, M. 2016. Experimental Evaluation of Mechanical Properties of Softwood using Acoustic Methods. BioResources, 11(1), pp. 503-518.

Rangavar, H. 2017. Wood-Cement Board Reinforced with Steel Nets and Woven Hemp Yarns: Physical and Mechanical Properties. Drvna industrija, 68(2), pp. 121-128.

Reis, J. P., de Moura, M. F. S. F., Silva, F. G. A., and Dourado, N. 2018. Dimensional optimization of carbon-epoxy bars for reinforcement of wood beams. Composites Part B, 139, pp. 163170 .

Rescalvo, F. J., Valverde-Palacios, I., Suarez, E., and Gallego, A. 2017. Experimental Comparison of Different Carbon Fiber 
Composites in Reinforcement Layouts for Wooden Beams of Historical Buildings. Materials, 10(10), pp. 1113-1132.

Rescalvo, F. J., Valverde-Palacios, I., Suarez, E., and Gallego, A. 2018. Experimental and analytical analysis for bending load capacity of old timber beams with defects when reinforced with carbon fiber strips. Composite Structures, 186, pp. 29-38.

Riggio, M., D'Ayala, D., Parisi, M. A., and Tardini, C. 2018. Assessment of heritage timber structures: Review of standards, guidelines and procedures. Journal of Cultural Heritage, 31, pp. 220-235.

Sáenz Reyes, J. T., Muñoz Flores, H. J., and Rueda Sánchez, A. 2011. Especies Promisorias de Clima Templado para Plantaciones Forestales Comerciales en Michoacán. Libro Técnico Núm. 10. SAGARPA-INIFAP-CIRPAC-Campo Experimental Uruapan. Uruapan, Michoacán, México. 213 pp.

Sanabria, S. J., Furrer, R., Neuenschwander, J., Niemz, P., and Sennhauser, U. 2011. Air-coupled ultrasound inspection of glued laminated timber. Holzforschung, 65(3), pp. 377-387.

Schober, K-U., Harte, A. M., Kliger, R., Jockwer, R., Xu, Q., and Chen, J-F. 2015. FRP reinforcement of timber structures. Construction and Building Materials, 97, pp. 106-118.

Sotomayor Castellanos, J. R., Guridi Gómez, L. I., y García Moreno, T. 2010. Características acústicas de la madera de 152 especies mexicanas. Velocidad del ultrasonido, módulo de elasticidad, índice material y factor de calidad. Base de datos. Investigación e Ingeniería de la Madera, 6(1), pp. 3-32

Sotomayor Castellanos, J. R., Carmona Delgado, I., Cervantes Móreles, I., Garduño Suárez, D., Jiménez Guzmán, D. Z., Lemus Durán, R., Maldonado Correa, D., Pérez Tello, A., Vaca Hernández, M A., and Valdez Velázquez, O. 2015. Madera laminada de Pinus pseudostrobus. Caracterización dinámica con métodos no destructivos. Investigación e Ingeniería de la Madera, 11(3), pp. 4-34.

Spycher, M., Schwarze, F.W.M.R., and Steiger, R. 2008. Assessment of resonance wood quality by comparing its physical and histological properties. Wood Science and Technology. 42(4), pp. 325-342.

Togay, A., Döngel, N., Söğütlü, C., Ergin, E., Uzel, M., and Güneş, S. 2017. Determination of the Modulus of Elasticity of Wooden Construction Elements Reinforced with Fiberglass Wire Mesh and Aluminum Wire Mesh. BioResources, 12(2), pp. 24662478.

Van Roy, N., Verstrynge, E., and Van Balen, K. 2018. A preventive conservation approach for historical timber roof structures. Journal of Cultural Heritage Management and Sustainable Development, 8(2), pp. 82-94.

Zhou, X. Y., Wang, Q., Li, J. H., and Zhang, Z. F. 2011. Comparative Study on Mechanics of Galvanized Steel Wire Mesh and GFRP Reinforced Wood for Timberwork on Chinese Plantation. Applied Mechanics and Materials, 71-78, pp. 32803283. 